\title{
PERAN EDUKASI GAYA HIDUP TERHADAP STATUS GIZI, STATUS FUNGSIONAL, DAN KUALITAS HIDUP PASIEN DIABETES MELITUS TIPE 2 LANJUT USIA
}

\author{
Laksmi Sasiarini $^{\star 凶}$, Ika A. Puspitasari** Sri Sunarti*
}

\begin{abstract}
Abstrak
Intervensi latihan fisik dan saran diet tinggi protein membantu memperlambat penurunan massa otot, sehingga secara tidak langsung dapat memperbaiki status gizi, status fungsional, dan kualitas hidup pada lansia penderita Diabetes Melitus (DM) tipe 2. Penelitian bertujuan untuk mengetahui perbedaan status gizi, status fungsional, dan kualitas hidup pada lansia penderita DM tipe 2 sebelum dan sesudah pemberian latihan fisik dan saran diet tinggi protein. Penelitian dilakukan secara eksperimental kohort selama 10 minggu. Subjek adalah 56 pasien DM tipe 2 di Poli Endokrin RSSA Malang yang 58\% adalah wanita dengan rerata usia $65,79 \pm 5,74$ tahun. Subjek dibagi secara acak ke dalam kelompok perlakuan dan tanpa perlakuan. Analisis statistik menggunakan uji independent T, Mann Whitney $\mathrm{U}$, dan uji T berpasangan. Penilaian rerata status gizi berdasarkan Mini Nutritional Assessment menunjukkan hasil normal. Rerata status fungsional berdasarkan Indeks Barthel menunjukkan ketergantungan ringan, dan rerata kualitas hidup berdasarkan SF 36 menunjukkan nilai yang bagus. Pada kelompok perlakuan, edukasi tentang latihan fisik dan diet tinggi protein didapatkan hasil yang signifikan untuk status gizi, status fungsional, dan kualitas hidup dibandingkan kelompok kontrol $(p<0,05)$. Didapatkan hasil yang signifikan pada kelompok perlakuan untuk status gizi, status fungsional, dan kualitas hidup sebelum dan sesudah intervensi $(p<0,05)$. Dapat disimpulkan bahwa status gizi, status fungsional, dan kualitas hidup pada lansia penderita DM tipe 2 berbeda secara bermakna antara kelompok tanpa perlakuan dengann kelompok perlakuan, serta terdapat peningkatan status gizi, status fungsional, dan kualitas hidup sebelum dan sesudah intervensi pada kelompok perlakuan.
\end{abstract}

Kata kunci: diet tinggi protein, kualitas hidup, lansia penderita Diabetes Mellitus tipe 2, status latihan fisik, gizi, status fungsional.

\section{THE ROLE OF LIFESTYLE EDUCATION PROGRAM ON NUTRITIONAL STATUS, FUNCTIONAL STATUS, AND QUALITY OF LIFE IN ELDERLY TYPE 2 DIABETIC PATIENTS}

\begin{abstract}
Physical exercise and high protein dietary advice help prevent muscle loss, and improve the nutritional status, functional status, and quality of life in elderly patients with type 2 Diabetes Mellitus (DM). This study aimed was to assess the differences in nutritional status, status functional, and quality of life in elderly patients with type $2 \mathrm{DM}$ before and after physical exercise and a high-protein diet advice. This experimental cohort study for 10 weeks involving 56 patients with type 2 DM at Endocrine Outpatient Clinic of Saiful Anwar Hospital Malang. The subject mostly were women (58\%) with average of age $65.79 \pm 5.74$ years. The subjects were randomly divided into treatment group and non-treatment group. The data was analyzed using Independent T-test, Mann Whitney U-Test and Paired T test. Mini nutritional assessment showed the average of nutritional status was normal, the average of functional status using Barthel Index showed mild dependence, and the average of quality of life using SF 36 showed good result. The treatment group showed significantly different of nutritional status, functional status, and quality of life compared to the control $(p<$ 0.05 ) and significantly different in nutritional status, functional status, and quality of life before and after intervention $(p<0.05)$. There were significantly different of the nutritional status, functional status, and quality of life in elderly patients with type $2 \mathrm{DM}$ between control and treatment groups. There were also increased nutritional status, functional status, and quality of life before and after the intervention in the treatment group.
\end{abstract}

Keywords: elderly patients with type 2 diabetes mellitus, functional status, high protein diet, nutritional status, physical excercise, quality of life.

* Lab. IImu Penyakit Dalam, Fakultas Kedokteran Universitas Brawijaya

${ }^{* *}$ Program Studi Pendidikan Dokter, Fakultas Kedokteran Universitas Brawijaya

E-mail: laksmi_sasiarini@ub.ac.id atau sri_sunarti.fk@ub.ac.id 


\section{Pendahuluan}

Jumlah penduduk usia lanjut di Indonesia mencapai peringkat lima besar terbanyak di dunia, yakni 18,1 juta pada tahun 2010 dan akan meningkat dua kali lipat menjadi 36 juta pada tahun 2025. Proporsi usia lanjut meningkat dari $6 \%$ pada tahun 1950-1990 menjadi 8\% saat ini. Proporsi tersebut diperkirakan meningkat menjadi $13 \%$ pada tahun 2025 dan 25\% pada tahun 2050. Pada tahun 2050 seperempat penduduk Indonesia merupakan penduduk usia lanjut, dibandingkan seperdua belas penduduk Indonesia saat ini. Isu penting terkait peningkatan populasi usia lanjut adalah perlunya rencana strategis perawatan kesehatan usia lanjut untuk meningkatkan kapasitas fungsional dan kualitas hidup. Adanya peningkatan yang cepat pada populasi berusia lebih dari 60 tahun dibandingkan populasi kelompok umur lainnya, disebabkan oleh peningkatan angka harapan hidup dan penurunan angka kelahiran. ${ }^{1}$

Penelitian ini penting untuk dilakukan mengingat populasi usia lanjut termasuk populasi yang cukup besar jumlahnya di Kota Malang. Kelompok lanjut usia yang diteliti adalah pasien penderita DM tipe 2. Pasien DM tipe 2 usia lanjut umumnya telah menderita komplikasi kronik dan mengalami gangguan baik status fungsional maupun nutrisi. Berdasarkan data International Diabetes Federation (IDF) tahun 2015 menyebutkan bahwa lebih dari $30 \%$ penderita DM berusia 60-69 tahun. ${ }^{2}$ Data Riskesdas tahun 2013 menunjukkan prevalensi DM sebesar $4,2 \%$ untuk pasien yang berusia 65 -74 tahun. $^{3}$

Sering dijumpai adanya kelompok lanjut usia dengan karakteristik yang sama, namun memiliki kondisi fisik yang berbeda. Beberapa dari lanjut usia tersebut masih dapat melakukan aktivitas sehari-harinya dengan baik dan mandiri. Sebaliknya pada beberapa individu menggantungkan hidupnya pada orang lain bahkan untuk aktifitas ringan harian. Pada orang usia lanjut sudah mulai terjadi penurunan fungsi di dalam tubuhnya, termasuk status gizi, status fungsional, yang akhirnya berdampak pada kualitas hidupnya. Terjadinya penurunan massa otot secara fisiologis pada lanjut usia sehingga meningkatkan angka risiko jatuh, penurunan status fungsional, gangguan mobilitas, dan sindroma frailty (sindrom klinis yang disebabkan oleh akumulasi proses menua). Penatalaksanaan yang tepat dibutuhkan untuk mencegah ataupun memperlambat penurunan status fungsional serta mempertahankan dan memperbaiki kualitas hidup mereka yang lanjut usia.

Berdasarkan alasan-alasan di atas, aktivitas fisik dan asupan protein merupakan faktor yang harus diseimbangkan. Latihan fisik tanpa asupan protein yang cukup akan menyebabkan tubuh menjadi lemah, keseimbangan protein yang negatif serta terjadi degradasi otot. Oleh karena itu, hubungan antara intensitas aktivitas fisik dan asupan protein pada status fungsional masyarakat usia lanjut perlu untuk dibuktikan lebih lanjut. Pada penelitian ini ingin diketahui peningkatan status gizi, status fungsional, dan kualitas hidup sebelum dan sesudah pemberian latihan fisik dan saran diet tinggi protein.

\section{Bahan dan Metode}

Penelitian ini menggunakan rancangan penelitian eksperimental kohort dengan mengikuti pasien selama 10 minggu. Penelitian ini telah mendapatkan persertujuan dari Komite Etik RSSA.

Sampel penelitian ini adalah pasien lanjut usia yang berobat ke Poli Endokrin RSUD Dr. Saiful Anwar Malang dan berusia di atas 55 tahun. Kriteria inklusi yang digunakan adalah pasien laki-laki atau wanita usia $\geq 55$ tahun; didiagnosis DM tipe 2 
dengan atau tanpa komplikasi; pasien rawat jalan di Poli Endokrin RSUD Dr. Saiful Anwar Malang; Nilai indeks Barthel antara 9-19; Bersedia menjadi responden penelitian dengan menandatangani informed consent. Sementara kriteria eksklusi meliputi: glukosa darah acak > 250mg/dl; kontraindikasi untuk dilakukan latihan fisik; meninggal dunia/drop out; memiliki penyakit-penyakit lain yang mempengaruhi studi fungsional seperti gagal ginjal, gagal jantung berat, retinopati berat, hipertensi stage 2, gagal hati, dan neuropati berat.

Semua subjek mendapatkan buku panduan mengenai aktivitas fisik yang harus dilakukan oleh pasien lanjut usia beserta berbagai daftar makanan dengan kandungan protein masing-masing yang nantinya dapat menjadi acuan untuk pasien dalam mengkonsumsi makanan sehari-hari. Selanjutnya subjek dibagi 2 kelompok berdasarkan urutan ganjil genap, yakni kelompok tanpa perlakuan dan kelompok perlakuan. Pada kelompok perlakuan secara intensif diminta untuk melakukan aktivitas fisik dan diet tinggi protein selama 10 minggu. Peneliti melakukan follow up setiap minggunya melalui telepon dan setiap bulannya bertemu dengan pasien secara langsung di poliklinik. Dilakukan pengukuran status gizi menggunakan Indeks Massa Tubuh (IMT), kuisioner Mini Nutritional
Assessment (MNA), status fungsional menggunakan kuisioner indeks Barthel, dan kualitas hidup menggunakan SF-36 pada semua subjek penelitian sebelum dan 10 minggu kemudian.

Data yang diperoleh dianalisis menggunakan komputer (SPSS versi 16.0). Uji beda dilakukan terhadap kelompok perlakuan dan kelompok kontrol. Data variabel sebaran normal dianalisis menggunakan statistik prametrik (uji tberpasangan). Data variabel sebaran tidak normal dianalisis menggunakan uji Mann Whitney U. Hasil dikatakan bermakna secara statistik bila didapatkan nilai $p<0,05$.

\section{Hasil}

Penelitian ini dilakukan pada 56 orang yang secara acak dibagi menjadi 2 kelompok, yaitu 28 orang pada kelompok tanpa perlakuan, dan 28 orang pada kelompok perlakuan. Pada Tabel 1 ditampilkan karakteristik subjek pada kedua kelompok sebelum perlakuan.

Hasil uji homogenitas yang dilakukan untuk kualitas hidup dan usia didapatkan nilai $p>0,05$, sehingga untuk kedua variabel tersebut datanya homogen. Uji Mann Whitney $\mathrm{U}$ digunakan untuk variabel status gizi, status fungsional, dan IMT karena sebaran data yang tidak normal $p>0,05$.

Tabel 1. Perbandingan karakteristik pasien DM tipe 2 pada kedua kelompok sebelum perlakuan

\begin{tabular}{lccc}
\hline \multicolumn{1}{c}{ Variabel } & $\begin{array}{c}\text { Kelompok Tanpa Perlakuan } \\
(\mathrm{n}=28)\end{array}$ & $\begin{array}{c}\text { Kelompok Perlakuan } \\
(\mathrm{n}=28)\end{array}$ & $\mathrm{p}$ \\
\hline Jenis kelamin & & & \\
Laki-laki & 10 & 14 & - \\
$\quad$ Perempuan & 18 & 14 & \\
Usia (tahun) & $63,46 \pm 5,90$ & $65,79 \pm 5,74$ & 0,96 \\
IMT (kg/m²) & $25,03 \pm 4,64$ & $25,69 \pm 4,49$ & 0,58 \\
Status gizi & $23,14 \pm 2,92$ & $24,35 \pm 2,27$ & 0,43 \\
Status fungsional & $17,43 \pm 1,39$ & $17,89 \pm 0,92$ & 0,17 \\
Kualitas hidup & $66,67 \pm 9,818$ & $68,39 \pm 9,134$ & 0,86 \\
\hline
\end{tabular}


Tabel 2. Perbandingan karakteristik pasien DM tipe 2 pada kedua kelompok setelah perlakuan

\begin{tabular}{lccc}
\hline Variabel & $\begin{array}{c}\text { Kelompok Tanpa Perlakuan } \\
(n=28)\end{array}$ & $\begin{array}{c}\text { Kelompok Perlakuan } \\
(n=28)\end{array}$ & $p$ \\
\hline IMT $\left(\mathrm{kg} / \mathrm{m}^{2}\right)$ & $25,08 \pm 4,53$ & $25,86 \pm 4,54$ & 0,65 \\
Status gizi & $23,41 \pm 2,535$ & $25,51 \pm 1,941$ & 0,55 \\
Status fungsional & $17,64 \pm 1,471$ & $18,64 \pm 0,621$ & 0,26 \\
Kualitas hidup & $69,46 \pm 9,263$ & $76,25 \pm 8,007$ & 0,85 \\
\hline
\end{tabular}

Tabel 3. Perbedaan status gizi, status fungsional, dan kualitas hidup pada pasien DM tipe 2 pada kelompok perlakuan

\begin{tabular}{lccc}
\hline & $\begin{array}{c}\text { Status Gizi } \\
(\mathrm{n}=28)\end{array}$ & $\begin{array}{c}\text { Status Fungsional } \\
(\mathrm{n}=28)\end{array}$ & $\begin{array}{c}\text { Kualitas Hidup } \\
(\mathrm{n}=28)\end{array}$ \\
\hline Sebelum perlakuan & 24,3750 & 17,8929 & 68,39 \\
Setelah perlakuan & 25,5179 & 18,6429 & 76,25 \\
$\mathrm{p}$ & $0,000^{* *}$ & $0,001^{* *}$ & $0,000^{*}$ \\
\hline${ }^{*}$ Analisis dengan uji t-berpasangan, signifikansi $\mathrm{p}<0,05$ & \\
${ }^{* *}$ Analisis dengan Uji Wilcoxon, signifikansi $p<0,05$ &
\end{tabular}

Hasil analisis uji independen $t$ atau uji Mann Whitney U (Tabel 2) menunjukkan bahwa setelah perlakuan tidak terdapat perbedaan yang signifikan $(p>0,05)$ antara kelompok perlakuan dan kelompok tanpa perlakuan.

Perbedaan status gizi, status fungsional, dan kualitas hidup pada pasien kelompok perlakuan ditampilkan pada Tabel 3. Hasil analisis uji $t$ berpasangan menunjukkan bahwa terdapat perbedaan yang signifikan pada status gizi, status fungsional, dan kualitas hidup sebelum dan sesudah dilakukan edukasi gaya hidup secara intensif.

\section{Pembahasan}

Status gizi adalah keadaan seseorang yang ditentukan oleh derajat kebutuhan fisik terhadap energi dan zat-zat yang diperoleh dari pangan dan makanan dan berhubungan erat dengan asupan energi, protein, dan aktivitas fisik. ${ }^{4}$ Asupan protein pada pasien DM (tanpa gangguan ginjal) berkisar 1-1,5 $\mathrm{g} / \mathrm{kgBB} / \mathrm{hari}$ atau $15-20 \%$ dari kalori total.
Asupan protein yang cukup pada pasien DM tipe 2 terbukti meningkatkan respons insulin terhadap karbohidrat tanpa mempengaruhi kadar glukosa darah. ${ }^{5}$

Pada pasien DM status gizi penting untuk terus dikontrol agar tidak mengalami kondisi hipoglikemia dan hiperglikemia. Pengukuran status gizi dilakukan menggunakan kuisioner MNA yang memiliki nilai sensitivitas dan spesifisitas yang cukup tinggi yaitu sensitivitas $96 \%$ dan spesifitas $98 \%{ }^{6}$ Hasil penelitian yang dilakukan pada individu lanjut usia yang menderita DM tipe 2 di RSUD dr. Saiful Anwar Malang menunjukkan bahwa rerata status gizi responden kelompok tanpa perlakuan dan kelompok perlakuan sebelum diberikan intervensi berupa diet tinggi protein dan latihan fisik tidak menunjukkan perbedaan yang signifikan. Namun, setelah diberikan intervensi intensif pada kelompok perlakuan, rerata status gizi pada kelompok perlakuan meningkat secara bermakna dibandingkan kelompok tanpa perlakuan. Hasil tersebut menunjukkan bahwa status gizi kelompok perlakuan menjadi lebih baik (peningkatan 
skor MNA) setelah diberikan latihan fisik dan saran diet tinggi protein secara intensif.

Selain itu, diketahui pula adanya hubungan yang signifikan antara latihan fisik dan pengaturan pola makan yang baik pada kelompok perlakuan $(p=0,000)$. Hasil ini juga didukung oleh penelitian Ninna Rohmawati yang menyatakan bahwa terdapat hubungan yang signifikan antara asupan makanan dan status gizi pada lansia di Kecamatan Sumbersari Kabupaten Jember $(p=0,001) .{ }^{7}$ Menurut Paddon dan Rasmussen menyatakan bahwa kecukupan protein total yang dikonsumsi dalam sehari akan meningkatkan sintesis protein di dalam tubuh. ${ }^{8}$ Selain itu, latihan fisik yang dilakukan secara teratur akan mempengaruhi pengeluaran tenaga yang sangat penting untuk pemeliharaan kesehatan fisik dan mental. ${ }^{1}$ Maka, saat seorang lanjut usia melakukan aktivitas fisik secara rutin dibutuhkan asupan protein dan gizi lainnya yang lebih besar.

Asupan makanan merupakan faktor yang berpengaruh langsung secara linier dalam menentukan status gizi seseorang. Saniawan menyatakan bahwa asupan makanan berpengaruh terhadap status gizi seseorang. ${ }^{9}$ Dwiyanti menjelaskan bahwa seseorang dengan asupan energi yang kurang, memiliki risiko 3,2 kali lebih besar untuk mengalami kekurangan gizi dibandingkan dengan subjek yang asupan energinya cukup..$^{10}$

Indeks massa tubuh merupakan salah satu indeks penilaian status gizi sederhana yang berkaitan dengan kekurangan dan kelebihan berat badan. Semakin besar nilai IMT seseorang, maka semakin tinggi tingkat kelebihan berat badannya. Salah satu kelemahan IMT adalah tidak memperhitungkan persentase massa otot atau massa lemak yang akan mempengaruhi hasil pengukuran IMT. Pada penelitian ini, baik pada kelompok kontrol maupun perlakuan didapatkan nilai IMT $\geq 25 \mathrm{~kg} / \mathrm{m}^{2}$, yang berarti semua subjek termasuk kategori obesitas (menggunakan kriteria untuk populasi Asia Pasifik). Berdasarkan data pada Tabel 2 diketahui tidak terdapat perbedaan yang bermakna antara kedua kelompok $(p=0,546)$. Rerata IMT pada kedua kelompok juga menunjukkan hasil yang tidak jauh berbeda. Bahkan, setelah diberikan perlakuan didapatkan nilai yang tidak berbeda signifikan. Hal ini karena adanya beberapa responden pada kelompok tanpa perlakuan yang rutin melakukan aktivitas fisik sesuai dengan petunjuk pada buku panduan yang diberikan. Penelitian Troms $\varnothing$ di Norwegia yang melibatkan 19,515 subjek berusia di atas 65 tahun menyebutkan bahwa IMT di bawah $25 \mathrm{~kg} / \mathrm{m}^{2}$ pada pria maupun wanita usia lanjut berkaitan dengan angka mortalitas yang lebih tinggi dibandingkan dengan kelompok obesitas. Sedangkan subjek dengan nilai IMT 25-29,9 $\mathrm{kg} / \mathrm{m}^{2}$ (kelompok overweight) mempunyai angka total mortalitas terendah. ${ }^{11}$

Secara umum, diabetes dan proses menua merupakan faktor risiko menurunnya status fungsional. Pada pasien diabetes, hal tersebut disebabkan akibat interaksi antara kondisi pasien, adanya neuropati perifer, gangguan penglihatan dan pendengaran, serta keseimbangan. Komplikasi neuropati perifer terjadi pada $50-70 \%$ pasien diabetes usia lanjut dan meningkatkan risiko terjadinya gangguan keseimbangan, atrofi otot, terbatasnya aktifitas fisik, dan meningkatnya risiko jatuh. ${ }^{12}$

Status fungsional diukur menggunakan kuisioner indeks Barthel yang memiliki nilai sensitivitas $94 \%$ hingga $95 \%$ dan nilai spesifisitas sebesar 80 hingga $85 \% .{ }^{13}$ Hasil penelitian yang dilakukan di Poli Endokrin RSUD dr.Saiful Anwar Malang pada pasien DM tipe 2 lanjut usia menunjukkan bahwa status fungsional kelompok tanpa perlakuan dan kelompok perlakuan tidak menunjukkan perbedaan tidak signifikan $(p=0,128)$. Berdasarkan penilaian menggunakan indeks 
Barthel, hampir seluruhnya berada pada tingkat ketergantungan ringan, yaitu terdapat beberapa aktivitas yang membutuhkan bantuan orang lain tetapi sebagian kegiatan yang lain masih bisa dikerjakan dengan mandiri. Meskipun berada pada tingkat ketergantungan ringan, namun dengan skor yang cukup bervariasi antara 12-19. Setelah pemberian intervensi, maka seluruh responden berada pada kategori ketergantungan ringan. Terdapat pula perbedaan rerata yang signifikan antara status fungsional pada kelompok perlakuan dan kelompok kontrol $(p=0,000)$. Namun responden pada kelompok perlakuan mengalami peningkatan nilai status fungsional secara signifikan setelah melakukan latihan fisik secara teratur dan mengatur pola makan selama 10 minggu. Hasil ini didukung oleh penelitian yang dilakukan oleh Donald $H$. Patterson yang menyatakan bahwa intervensi latihan fisik (termasuk latihan aerobik atau resistance training) pada lanjut usia, akan menunjukkan perubahan psikologis dan status fungsional. ${ }^{14}$

Selain itu, menurut Almatsier, ketidakcukupan protein berkontribusi pada penyusutan otot (sarkopenia), rendahnya status imunitas, dan perlambatan penyembuhan luka. ${ }^{4}$ Sarkopenia ditandai dengan berkurangnya massa otot, kekuatan serta kelenturannya sebagai akibat perubahan pada serabut otot, sintesis protein dan fungsi mitokondria. Bahkan, pada orang sehat kekuatan otot terutama pada ekstremitas bawah mulai menurun pada usia 25 tahun. Proses tersebut bertambah cepat setelah usia 65 tahun dan mencapai puncaknya (sampai 50\%) pada usia 80 tahun. ${ }^{15}$ Kekurangan protein dapat mengakibatkan kelemahan, menurunnya massa otot dan daya tahan tubuh. Sehingga, dengan perbaikan protein akan memperlambat penurunan massa otot dan memperbaiki status fungsional. Penelitian National Institute on Aging menyatakan bahwa fisik lanjut usia yang berusia 90 tahun menjadi lemah. ${ }^{16}$ Kemudian diadakan penelitian dengan latihan otot tubuh yang sederhana selama 10 minggu. Hasil menunjukkan bahwa lansia yang duduk di kursi roda dapat menggunakan tongkat untuk berjalan. Resistance training atau latihan beban dikatakan dapat meningkatkan massa otot dan memperlambat munculnya sarkopenia akibat pertambahan usia.

Latihan kekuatan otot merupakan contoh latihan yang aman dilakukan jika gerakan latihan dilakukan dengan perlahan, bertahap, terkontrol, dan benar. Sebuah review dari Cochrane pada tahun 2009 yang melibatkan 121 studi randomized controlled trial (RCT), mengemukakan bahwa latihan kekuatan otot yang bersifat progresif merupakan intervensi yang efektif untuk meningkatkan fungsi fisik pada usia lanjut. ${ }^{17}$ Latihan kekuatan otot menyebabkan gangguan mikroskopis pada sel-sel otot (katabolisme), yang selanjutnya dengan cepat diperbaiki (anabolisme). Sel otot beradaptasi dengan beban yang diberikan, dengan cara memperbesar volumenya (hipertrofi) dan melibatkan jumlah sel saraf yang lebih banyak untuk membantu kontraksi.

Kualitas hidup seseorang dapat dinilai dari aspek fisik, mental, sosial, dan spiritual. Kualitas hidup diukur menggunakan SF-36 dengan nilai sensitivitas $74 \%$ dan nilai spesifitas $81 \% .{ }^{18}$ Hasil penelitian ini menunjukkan bahwa kualitas hidup lanjut usia yang berada pada kedua kelompok sebelum diberikan perlakuan tidak menunjukkan perbedaan yang signifikan. Namun, setelah diberi perlakuan intensif menunjukkan perbedaan kualitas hidup yang signifikan pada kelompok tanpa perlakuan dan kelompok perlakuan. Pernyataan ini didukung oleh penelitian Carlos Soares Pernambuco pada 125 subjek yang diberikan latihan fisik selama 16 minggu, didapatkan hasil bahwa kelompok kontrol yang tidak atau jarang melakukan aktivitas fisik mengalami 
perubahan kualitas hidup yang tidak signifikan, sedangkan pada kelompok yang aktif, menunjukkan perubahan kualitas hidup yang lebih baik. Peningkatan kualitas hidup terbaik didapatkan mulai minggu ke 10 hingga minggu ke 16 setelah dilakukan intervensi exercise training pada anggota gerak atas dan anggota gerak bawah. ${ }^{19}$

Hasil ini juga didukung oleh penelitian Jeklin Linda yang menyatakan bahwa terdapat hubungan antara latihan fisik dan kualitas hidup Lansia di Kecamatan Dimembe, Kabupaten Minahasa Utara. ${ }^{20}$ Didapati ada hubungan yang signifikan antara latihan fisik dan kualitas hidup keseluruhan dengan nilai $p=0,001$. Surinela dan Agus menyatakan bahwa olahraga yang dilakukan secara tepat dan teratur merupakan faktor yang sangat penting dalam mencegah stres. ${ }^{21}$ Tidak hanya berpengaruh pada fungsi tubuh manusia, tetapi juga menimbulkan suatu kesenangan tersendiri. Olahraga seperti yoga, latihan pernafasan reiki, tai chi sangat berpengaruh pada banyaknya endorfin yang dihasilkan. Olahraga vaskular lain seperti jalan kaki, jogging, senam, dan berenang sangat memengaruhi jumlah energi cadangan tubuh, memperbaiki kelancaran sirkulasi makro dan mikro sehingga organ dan sistem tubuh bekerja dengan lebih baik. Sistem tubuh yang lebih baik akan mengurangi disabilitas fisik yang pada akhirnya akan menurunkan stres. Dengan meningkatkan kekuatan otot akan memperlambat munculnya penurunan fungsi tubuh sehingga orang usia lanjut dapat tetap menjalankan aktifitas fisik sehari-hari tanpa ketergantungan terhadap orang lain. Aktifitas fisik yang dilakukan secara teratur secara nyata juga memperbaiki mood dan kesehatan mental serta secara efektif berperan sebagai bagian terapi depresi. ${ }^{16}$

Perbedaan status gizi, status fungsional, dan kualitas hidup dirasakan manfaatnya oleh responden kelompok perlakuan. Hasil wawancara tidak terstruktur didapatkan bahwa terdapat responden yang merasakan perbedaan pada kualitas hidup dan kondisi tubuh yang lebih bugar, tidur yang lebih nyenyak, serta perbedaan nafsu makan menjadi lebih baik. Beberapa responden juga mengalami perubahan kendali glukosa darah yang lebih baik karena pengaturan pola makan yang baik dan latihan fisik yang teratur. Perubahan gaya hidup merupakan poin penting pengendalian glukosa darah yang harus disampaikan melalui edukasi yang terstruktur, berulang dan berkelanjutan. Edukasi sebaiknya berisi tentang pengetahuan, keahlian (skill), strategi perubahan perilaku, yang berkaitan dengan perawatan diri (self-care), yang dapat membantu pasien untuk dapat hidup lebih baik.

\section{Kesimpulan}

Terjadi perubahan status gizi, status fungsional, dan kualitas hidup yang signifikan pada penderita DM tipe 2 lanjut usia di Poliklinik Endokrin RSUD dr. Saiful Anwar Malang setelah secara intensif melakukan latihan fisik dan diet tinggi protein selama 10 minggu.

\section{Daftar Pustaka}

1. Setiati S. Geriatric Medicine, Sarkopenia, Frailty dan Kualitas Hidup Pasien Usia Lanjut: Tantangan Masa Depan Pendidikan, Penelitian dan Pelayanan Kedokteran di Indonesia. Jurnal Kedokteran Indonesia. 2013; 1(3): 234242.

2. International Diabetes Federation. IDF Diabetes Atlas. $7^{\text {th }}$ Edition. 2015

3. Kemetrian Kesehatan RI. Riset Kesehatan Dasar. Badan Penelitian dan Pengembangan Kesehatan Kemetrian Kesehatan RI. 2013.

4. Almatsier S. Prinsip Dasar IImu Gizi Jakarta: Gramedia Pustaka Utama, 2004. 
5. Evert $A B$, Boucher JL, Cypress $M$, Dunbar SA, Franz MJ, Mayer-Davis EJ et al. Nutrition Therapy Recommendations for the Management of Adults With Diabetes. Diabetes Care. 2013; 36: 3821-3842.

6. Kaiser MJ, Bauer2 JM, Ramsch C, Uter W, Guigoz Y, Cederholm T, Thomas $D R$, Anthony $P$ et al. Validation of The Mini Nutritional Assessment Short-Form (MNA-SF) : A Practical Tool For Identification of Nutritional Status. The Journal of Nutrition Health. 2009; 13(9): 782-788

7. Rohmawati N. Asupan Makan, dan Status Gizi pada Lansia di Kabupaten Jember. Jember. (Skripsi). Tidak Diterbitkan. Jember: Universitas Jember. 2013.

8. Paddon-Jones D, Rasmussen BB. Dietary Protein Recommendations and The Prevention of Sarcopenia: Protein, Amino Acid Metabolism and Therapy. Curr Opin Clin Nutr Metab Care. 2009; 12(1): 86-90.

9. Saniawan IM. Status Gizi pada Lanjut Usia pada Banjar Paang Tebel di Desa Peguyangan Kaja Wilayah Kerja Puskesmas III Denpasar Utara. Jurnal IImiah Keperawatan. 2009; 2(1): 45-49.

10. Dwiyanti D, Hadi H, Susetyowati. Pengaruh Asupan Makanan terhadap Kejadian Malnutrisi di Rumah Sakit. Jurnal Gizi Klinik Indonesia. 2004; 1(1): 1-7.

11. Kvamme JM, Holmen J, Wilsgaard T, Florholmen J, Midthjell K, Jacobsen BK. Body Mass Index and Mortality in Elderly Men and Women: The Tromsø and HUNT studies. I Epidemiol Community Health. 2011; 10: 1-7.

12. Kirkman MS, Briscoe VJ, Clark N, Florez $\mathrm{H}$, Halter JB, Huang ES et al. Diabetes in Older Adults. Diabetes Care. 2012; 35: 2650-2664.
13. Sulter G, Steen C, De Keyser J. 2009. Use of Barthel Index and Modified Rankin Scale in Acute Stroke Trials. Stroke. 1999; 30(8) :1538-41.

14. Patterson DH. Physical Activity and Fungtional Limitations in Older Adults : A Systematic Review Related to Canada's Physical Activity Guidlines. Journal of Behavioral Nutrition and Physical Activity. 2010; 7(38):1-22.

15. Concannon LG, Grierson MJ, Harrast MA. Exercise in the Older Adult: From the Sedentary Elderly to the Masters Athlete. Physical Medicine And Rehabilitation. 2012; 4: 833-839.

16. Kinsela K, He W. An Aging World: International Population Reports. National Institute of Aging. 2008.

17. Liu C, Latham NK. Progressive Resistance Strength Training for Improving Physical Function in Older Adults. Cochrane Database Syst Rev. 2009; 3:1-227

18. Ware JE. SF-36 Health Survey Update. Spine. 2000; 25(24):3130-3139.

19. Pernambuco CS, Rodrigues $M B$, Bezerra JCP, Carrielo A, Oliveira Fernandes $A D$, Souza Vale RG, Dantas EHM. Quality of Life, Elderly and Physical Activity. Sci Res. 2012; 4(2):88-93.

20. Tambariki JL. Latihan Fisik dan Kualitas Hidup pada Lansia di Kecamatan Dimembe Kabupaten Minahasa Utara. JKU. 2012; 1(1):73-83.

21. Surilena, AD. Faktor-faktor yang Mempengaruhi Depresi pada Lansia di Jakarta. Majalah Kedokteran Damianus. 2006; 5(2):115-129. 